\title{
Selection and socialization effects of fraternities and sororities on US college student substance use: a multi-cohort national longitudinal study
}

\author{
Sean Esteban McCabe', John E. Schulenberg², Lloyd D. Johnston ${ }^{3}$, Patrick M. O'Malley ${ }^{3}$, \\ Jerald G. Bachman ${ }^{3}$ \& Deborah D. Kloska \\ University of Michigan, Substance Abuse Research Center, Ann Arbor, MI,' Institute for Social Research and Department of Psychology, University of Michigan, \\ Ann Arbor, MI2 and Institute for Social Research, University of Michigan, Ann Arbor, MI, USA ${ }^{3}$
}

Correspondence to:

Sean Esteban McCabe

Interim Director and Assistant Research Scientist

University of Michigan

Substance Abuse Research Center

2025 Traverwood, Suite C

Ann Arbor

MI 48105-2194

USA

Tel: (734) 9986510

Fax: (734) 9986508

E-mail: plius@umich.edu

Submitted 9 February 2004;

initial review completed 26 May 2004;

final version accepted 19 November 2004

\begin{abstract}
Aims To examine how membership in fraternities and sororities relates to the prevalence and patterns of substance use in a national sample of full-time US college students.

Design Nationally representative probability samples of US high school seniors (modal age 18 years) were followed longitudinally across two follow-up waves during college (modal ages 19/20 and 21/22).

Setting Data were collected via self-administered questionnaires from US high school seniors and college students.

Participants The longitudinal sample consisted of 10 cohorts (senior years of 1988-97) made up of 5883 full-time undergraduate students, of whom 58\% were women and $17 \%$ were active members of fraternities or sororities.

Findings Active members of fraternities and sororities had higher levels of heavy episodic drinking, annual marijuana use and current cigarette smoking than non-members at all three waves. Although members of fraternities reported higher levels than non-members of annual illicit drug use other than marijuana, no such differences existed between sorority members and nonmembers. Heavy episodic drinking and annual marijuana use increased significantly with age among members of fraternities or sororities relative to non-members, but there were no such differential changes for current cigarette use or annual illicit drug use other than marijuana.

Conclusions The present study provides strong evidence that higher rates of substance use among US college students who join fraternities and sororities predate their college attendance, and that membership in a fraternity or sorority is associated with considerably greater than average increases in heavy episodic drinking and annual marijuana use during college. These findings have important implications for prevention and intervention efforts aimed toward college students, especially members of fraternities and sororities.
\end{abstract}

KEYWORDS College students, fraternity, sorority, substance use.

\section{INTRODUCTION}

Substance use tends to increase among American adolescents who leave home and begin college (e.g. Schulenberg et al. 1994; Baer, Kivlahan \& Marlatt 1995;
Bachman et al. 1997, 2002). National epidemiological studies have examined the prevalence of substance use among college students and found that alcohol is the most commonly used drug, followed by tobacco and marijuana (Gfroerer, Greenblatt \& Wright 1997; O’Malley \& 
Johnston 2002; Johnston et al. 2004). The use of marijuana and other illicit drugs has increased significantly among college students in the United States over the past decade (Gledhill-Hoyt et al. 2000; Strote, Lee \& Wechsler 2002; Mohler-Kuo, Lee \& Wechsler 2003; Johnston et al. 2004). Although previous research has examined the prevalence of substance use other than alcohol use among college students in general (Presley, Meilman \& Cashin 1996; Gledhill-Hoyt et al. 2000; Johnston et al. 2004), less attention has been given to substances other than alcohol among fraternity and sorority members specifically. In the context of American colleges and universities, social fraternities and sororities refer to organizations that have existed in the United States since the 1820 s and are usually overseen by an alumni corporation or its respective national organization. These social organizations often have initiation rites for new members to join and sometimes maintain their own housing. The few national studies that have examined the association between illicit drug use and fraternity and sorority membership have found higher prevalence rates of marijuana use (Bell, Wechsler \& Johnston 1997; Mohler-Kuo et al. 2003) and ecstasy use (Strote et al. 2002; Yacoubian 2003) among fraternity and sorority members.

Entering and being in college tend to be particularly related to heavy alcohol use; college students tend to drink more heavily than their non-college peers (Bachman et al. 1997, 2002; Gfroerer et al. 1997; O'Malley \& Johnston 2002; Schulenberg \& Maggs 2002; Office of Applied Studies 2003; Johnston et al. 2004), and those college students who belong to fraternities and sororities tend to be the heaviest drinkers (Cashin, Presley \& Meilman 1998; Wechsler et al. 2000; Wechsler et al. 2002). The national prevalence of heavy episodic drinking among college students has remained steady for the past decade, with approximately two in every five students engaging in this drinking behavior (O'Malley \& Johnston 2002; Wechsler et al. 2002; Johnston et al. 2004). However, the national prevalence of heavy episodic drinking among fraternity and sorority members is much higher, approximately $65 \%$, and the rate is approximately $80 \%$ among those members residing in fraternity or sorority houses (Cashin et al. 1998; Wechsler et al. 2002). Active members of fraternities and sororities also suffer more negative alcohol-related consequences compared to their less active or non-affiliated college peers. For instance, Cashin et al. (1998) found that driving under the influence of alcohol, experiencing hangovers and missing classes as the result of alcohol consumption were significantly higher among more active fraternity members relative to fraternity members who were less involved, sorority members or non-members. Additionally, Schulenberg \& Maggs (2002) report that members of fraternities and sororities tend to be over-represented in chronic and increasing trajectories of heavy episodic drinking that have been shown to be associated with significantly more harmful alcohol-related correlates and consequences (Schulenberg et al. 1996).

\section{Selection and socialization effects}

Consideration of selection and socialization effects is central to understanding how substance use relates to fraternity and sorority membership. Selection effects refer to the influence of individual characteristics in steering an individual toward certain experiences, organizations or environments. Socialization effects refer to the influence of experiences, organizations or environments on the individual (e.g. Pascarella \& Terenzini 1991). The two effects often work in conjunction: for example, undergraduate students who are heavy drinkers before starting college may tend to select specific fraternities and sororities with a reputation for 'partying' and heavy drinking. In turn, being a member of such fraternities or sororities serves to increase their heavy drinking. Borsari \& Carey (1999) suggested in their review of the literature on fraternity drinking that 'this process of selective affiliation leads to a mutually reinforcing system' (p. 32). Bachman et al. (1997) commented: 'One of the challenges facing researchers is that of distinguishing between the preexisting differences that lead different individuals to choose different environments on the one hand, and the actual impacts of the new environments on the other hand' (p. 180).

Several studies have found evidence for selection effects in that students who engage in heavier alcohol use before college go on to join fraternities or sororities (e.g. Wechsler et al. 1994; Baer et al. 1995; Lo \& Globetti 1995; Read et al. 2002). Studies have also found that high school students who experience alcohol-related problems such as drinking and driving are more likely to join fraternities and sororities in college (e.g. Lo \& Globetti 1995). Baer et al. (1995) followed a sample of 366 heavydrinking high school students to freshmen year of college and found that male students who engaged in heavy drinking during their senior year of high school were more likely to join fraternities in college. However, these researchers found an important gender difference: women who were heavy drinkers in high school were not more likely than non-heavy drinkers to join sororities while in college. Baer et al. (1995) concluded that 'both dispositional factors (e.g. conduct history) and exposure to high-risk environments (e.g. fraternities) are associated with changes in drinking patterns and alcohol dependence as young people enter college' (p. 59).

Several researchers have also found evidence for socialization effects for heavy drinking, in that students engage in heavier alcohol use once they join a fraternity 
or sorority (e.g. Lo \& Globetti 1995; Cashin et al. 1998; Sher, Bartholow \& Nanda 2001; Bartholow, Sher \& Krull 2003). For instance, Lo \& Globetti (1995) examined the potential impact of socialization among first-year undergraduate students and found that members of fraternities and sororities were significantly more likely to increase the frequency of their drinking over time relative to nonmembers. An important gender difference was again observed: among women, sorority members were almost five times more likely than non-members to increase from low-frequency drinking in high school to high-frequency drinking in college; for men, fraternity members were only three times more likely than non-members to report such an increase (Lo \& Globetti 1995).

Despite the advances made in examining selection and socialization effects among US college students, there are several important limitations in past research. First, a great deal of attention has been given to selection and socialization effects on alcohol use among fraternity and sorority members, but little attention has been given to these effects related to substance use other than alcohol. Secondly, several studies have focused on samples drawn from single institutions; this limits the potential generalizability of the findings to college students nationally because past research has found wide variation in drug use between universities (Bell et al. 1997). Thirdly, previous national efforts have been cross-sectional and have not examined selection effects by tracking samples prospectively from high school through college. Given these gaps, there is a need for research that follows national samples of high school students prospectively through college (e.g. Lo \& Globetti 1995).

The present study, which draws on national panel data from the Monitoring the Future (MTF) project, includes 10 cohorts of nationally representative samples of high school seniors to examine how substance use during high school is related to subsequent collegiate membership in fraternities and sororities (i.e. selection effects). This study also examines the influence of membership in fraternities or sororities on subsequent substance use while in college (i.e. socialization effects). In addition, because existing research suggests that gender differences exist with respect to collegiate drinking patterns (e.g. Berkowitz \& Perkins 1987), risk factors (e.g. McCabe 2002) and socialization effects (e.g. Bartholow et al. 2003; Lo \& Globetti 1995), we examined whether selection and socialization effects vary as a function of gender.

\section{METHOD}

The present study used national panel data from the MTF project (Bachman et al. 2002; Johnston et al. 2004). Based on a three-stage sampling procedure, the MTF project has surveyed nationally representative samples of approximately 17000 high school seniors each year since 1975, using questionnaires administered in classrooms. Approximately 2400 high school seniors are selected for biennial follow-ups using mailed questionnaires. The biennial follow-up surveys begin 1 year after high school for one random half of each cohort and 2 years after high school for the other half. For purposes of these analyses, the two halves were combined (combining the first and second years of college and the third and fourth years of college) due to sample size concerns and lack of significant differences across the two halves on substance use measures. In addition, the first and second years of college are, arguably, more similar and often quite distinct from the third and fourth years (and by the third year, most students are 21 years old and able to drink legally). Individuals who used illicit drugs in high school were over-sampled in the follow-up surveys. Corrective weighting was used in the analyses to compensate for the effects of unequal probabilities of selection. The project design and procedures are described in more detail elsewhere (e.g. Bachman, Johnston \& O'Malley 2001; Johnston et al. 2004).

\section{Sample}

The sample for the present study consisted of respondents who were surveyed as high school seniors (wave 1) in 1988-1997, and who were surveyed in their first and/or second biennial follow-up surveys (waves 2 and 3, respectively) in 1989-2001. The 10 cohorts were combined for these analyses (preliminary analyses revealed few cohort $\times$ fraternity/sorority membership interactions within or across time). Given the aims of the present study, we limited our attention to those who were full-time students attending a four-year college or university at wave 2 and/ or wave 3 . At wave 2 this included 5883 respondents, of which $58 \%$ were women and $17 \%$ were members of fraternities or sororities; at wave 3 this included 5211 respondents, of whom $59 \%$ were women and $21 \%$ were members of fraternities or sororities. The longitudinal analyses were conducted with 4299 respondents who provided data at all three waves (longitudinal sample). Of those in our sample present at wave 2, 73\% were retained at wave 3 . In this longitudinal sample, 271 respondents at wave 3 were attending college half time or less. Attrition analyses revealed that, compared to those who participated at wave 2 but not wave 3 , those retained in the longitudinal sample for all three waves were more likely to be female and white; they also had lower wave 2 rates of current and annual marijuana use, illicit drug use other than marijuana and current cigarette smoking. There were no significant differences between those excluded and retained in terms of wave 2 membership in 
fraternities and sororities, current alcohol use or heavy episodic drinking.

\section{Measures}

Heavy episodic drinking was measured using the following item: 'Think back over the last 2 weeks. How many times have you had five or more drinks in a row?' The response scale was (1) none, (2) once, (3) twice, (4) three to five times, (5) six to nine times and (6) 10 or more times.

Current alcohol use was measured using the following item: 'On how many occasions (if any) have you had alcohol to drink - more than just a few sips-during the last 30 days?' The response scale was (1) no occasions, (2) one to two occasions, (3) three to five occasions, (4) six to nine occasions, (5) 10-19 occasions, (6) 20-39 occasions and (7) 40 occasions or more.

Current cigarette use was measured using the following item: 'How frequently have you smoked cigarettes during the past 30 days?' The response scale was: (1) none, (2) less than one cigarette per day, (3) one to five cigarettes per day, (4) about half a pack per day, (5) about one pack per day, (6) about 1.5 packs per day and (7) two or more packs per day.

Annual marijuana use was measured using the following item: 'On how many occasions (if any) have you used marijuana during the last 12 months?' The response scale was the same as for current alcohol use.

Other illicit drug use-including LSD, psychedelics other than LSD, cocaine, heroin, narcotics other than heroin, amphetamines, barbiturates and tranquilizerswas measured with the following two separate questions: 'On how many occasions (if any) have you used [specified drug class] ... (a) during the last 12 months or (b) during the last 30 days?' The response scale for each substance was the same as for current alcohol use. The mean of the eight substances was calculated separately for current and annual other illicit drug use.

Full-time college student status was based on respondents reporting being full-time students at a four-year college during March of the year in question at waves 1 and 2 .

Fraternity/sorority membership was defined with a single item asking whether an individual was an active member of a fraternity or sorority (excluding honorary ones). Based on the fraternity or sorority membership status at wave 2 (first and second years of college for most respondents) and wave 3 (third and fourth years of college), four mutually exclusive groups were formed for the longitudinal analyses. The first group, 'member waves 2 and 3', included college students who belonged to a fraternity or sorority during both waves 2 and 3 . The second group, 'member neither wave', included students who did not belong to a fraternity or sorority at either point. The third group, 'member wave 2 only', included students who belonged to a fraternity or sorority during wave 2 but not at wave 3 . The fourth group, 'member wave 3 only', included students who did not belong to a fraternity or sorority at wave 2 but were members at wave 3 .

\section{Statistical analyses}

Analyses included (1) cross-sectional comparison of the prevalence and mean levels of substance use between subgroups of college students and (2) examination of the patterns of substance use over time based on membership in fraternities and sororities. Given the research questions, analysis of variance (ANOVA) was selected as an appropriate analytical strategy (ANOVAs tend to be robust to violations of statistical assumptions). Prevalence estimates and their standard errors were adjusted by weighting the data; analyses were conducted using SPSS version 11.0. To address the research questions, we conducted full-factorial (fraternity/sorority membership $\times$ gender) cross-sectional ANOVAs and full-factorial repeated-measures ANOVAs.

\section{RESULTS}

Cross-sectional prevalence and mean levels of substance use $\times$ fraternity/sorority membership

To begin, prevalence rates of substance use at waves 1 and 2 were examined for four distinct groups of college students based on gender and fraternity/sorority membership status at wave 2 . As shown in Table 1, alcohol was the most commonly used substance for all four groups, followed by cigarettes, marijuana and illicit drugs other than marijuana combined. Prevalence rates of substance use were compared using $\chi^{2}$ tests. Among males, the use of substances tended to be higher-in some cases significantly higher - on nearly all drugs for fraternity members than for non-members, at both waves 1 and 2 . For example, wave 1 rates of heavy episodic drinking were $47 \%$ for high school men who went on to become fraternity members and $27 \%$ for eventual non-members; by wave 2 , the rates were $70 \%$ and $42 \%$, respectively. The wave 1 rate of current marijuana use was 19\% among eventual fraternity members and 11\% among eventual non-fraternity members; by wave 2 , the rates were $26 \%$ and $17 \%$, respectively. The differences for women were similarly large at wave 1 for alcohol and cigarette use, but considerably smaller (or even reversed slightly) for the various illicit drugs. Thus, the wave 1 rate of heavy episodic drinking was $26 \%$ for eventual sorority members versus $16 \%$ for eventual non-sorority members; by wave 


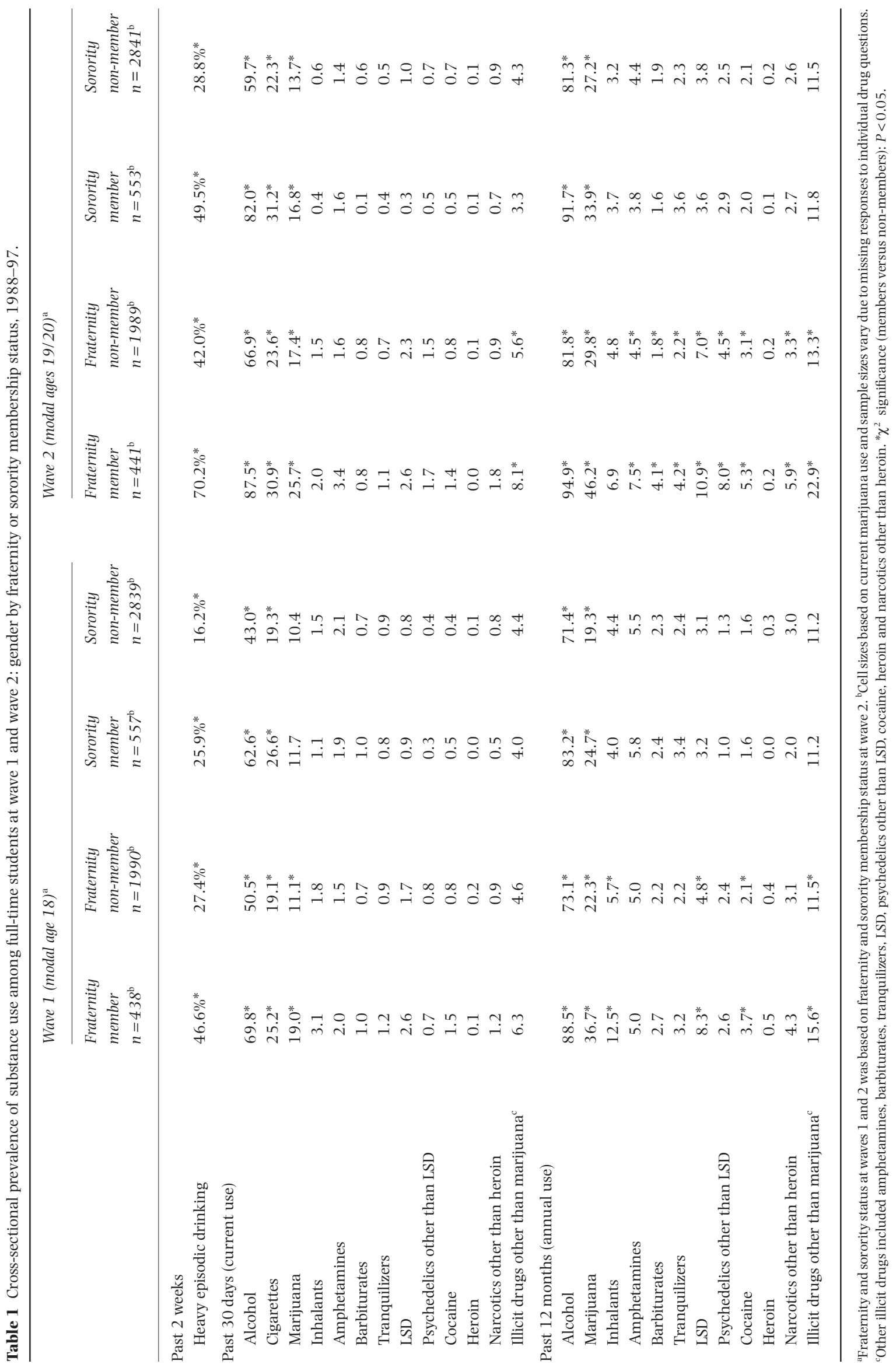


2 , the rates were $50 \%$ and $29 \%$, respectively. However, for current marijuana use the difference at wave 1 was $12 \%$ versus $10 \%$, respectively; by wave 2 , it was $17 \%$ and $14 \%$, respectively (note that the differences in annual marijuana use rates were greater). Of particular interest, the current and annual rates of illicit drug use other than marijuana were nearly identical for (eventual) sorority and non-sorority women at both waves 1 and 2 .

To examine substance use more systematically as a function of fraternity or sorority membership status and gender, full factorial analyses of variance (ANOVAs) were conducted separately at waves 1,2 and 3. By examining wave 1 substance use as a function of wave 2 fraternity/ sorority membership, we can begin to consider selection effects. Table 2 depicts the cell sizes, means and standard deviations for the substance use measures across all three waves. The ANOVA results are summarized in Table 3. Most notably, the ANOVA results showed that the main effect for membership in fraternities and sororities was significant at wave 1 for all substance use indices except current and annual illicit drug use other than marijuana. This highlights the pervasiveness of selection effects across these substances.

Gender had a significant effect at each wave for heavy episodic drinking, current alcohol use, marijuana use and illicit drug use other than marijuana, with men having higher rates than women. Gender differences were not significant at any of the waves for current cigarette use. For heavy episodic drinking, marijuana use and illicit drug use other than marijuana (at wave 2 only), the membership and gender main effects were qualified, at least to some extent, by the significant membership $\times$ gender interactions at each of the waves. These interactions were examined with post hoc tests. In each case at each wave, member versus non-member differences were significantly greater for men than for women.

\section{Longitudinal analyses of substance use $\times$ fraternity/ sorority membership}

The cross-sectional analyses were helpful to show how fraternity and sorority membership relates to substance use, both before and during college. To consider the role of selection and socialization effects more fully, we examined the course of substance use across the three waves as a function of fraternity/sorority membership and gender. Table 4 depicts the means and standard deviations for substance use measures across four distinct groups of fraternity and sorority membership (member both waves, member neither wave, member wave 2 only and member wave 3 only) by gender. Based on the prevalence rates, the dependent variables chosen for these analyses included heavy episodic drinking, current cigarette use, annual marijuana use and annual illicit drug use other than marijuana. Figures 1 and 2 illustrate heavy drinking and annual marijuana use, respectively, over time $\times$ fraternity/sorority membership and gender.

Full factorial repeated-measures analyses of variance were used to examine change over time in substance use $\times$ fraternity and sorority membership status and gender. The results from these analyses are summarized in Table 5. In these analyses, each substance was analyzed in a separate model as a set of dependent variables across all three time-points, and the significance of the multivariate effects was based on Pillai's trace. Given our research questions, as well as the small to moderate correlations among the substance use indices, focusing on each of the indices separately was appropriate.

As is evident in Table 5, the effect for time (i.e. increasing age) was significant for heavy episodic drinking, current cigarette use and annual marijuana use, indicating that overall rates of use of these substances increased over time among college students. There was no significant main effect for time for the use of illicit drugs other than marijuana. The two-way interaction for time $\times$ fraternity/ sorority membership was significant for heavy episodic drinking (see Fig. 1) and annual marijuana use (see Fig. 2) but not for current cigarette smoking or annual illicit drug use other than marijuana. Those who were members of fraternities and sororities experienced greater linear increases in heavy episodic drinking and annual marijuana use relative to non-members. Most notably, undergraduate men who joined fraternities early in their college careers and then became inactive during their third or fourth year of college (member wave 2 only) experienced a slight decrease in heavy episodic drinking between wave 2 and wave 3 . In contrast, undergraduate men who joined a fraternity during their third or fourth year of college (member wave 3 only) continued to increase in their heavy episodic drinking between wave 2 and wave 3 . We view this as evidence of socialization effects. Additionally, the two-way time $\times$ gender interaction effect was significant for marijuana and cigarette use, indicating that the overall increases in substance use over time were greater for college men than for college women. None of the three-way interaction effects (time $\times$ fraternity/sorority membership $\times$ gender) was significant.

\section{DISCUSSION}

Substance misuse remains the leading cause of preventable death among undergraduate students in the United States (Hingson et al. 2002). The findings from the present study add further evidence to the growing literature demonstrating that members of fraternities and 


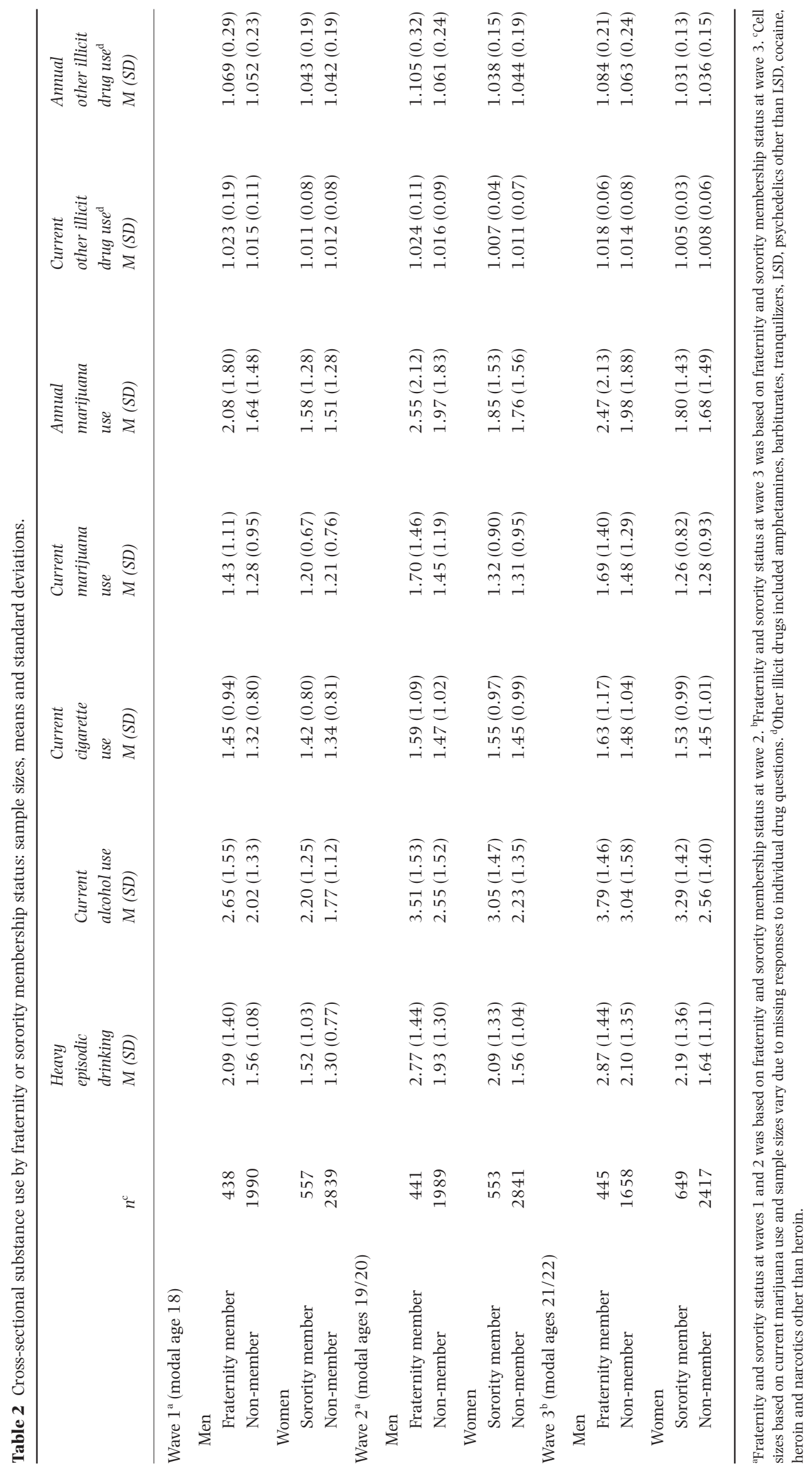


Table 3 Summary of analyses of variance cross-sectional results: waves 1, 2, 3.

\begin{tabular}{|c|c|c|c|c|c|c|c|}
\hline $\begin{array}{l}\text { Measurement occasions } \\
\text { and factors }\end{array}$ & $\begin{array}{l}\text { Heavy } \\
\text { episodic } \\
\text { drinking }^{\mathrm{a}}\end{array}$ & $\begin{array}{l}\text { Current } \\
\text { alcohol } \\
u_{s e} e^{b}\end{array}$ & $\begin{array}{l}\text { Current } \\
\text { cigarette } \\
\text { use }^{\mathrm{c}}\end{array}$ & $\begin{array}{l}\text { Current } \\
\text { marijuana } \\
\text { use }^{\mathrm{d}}\end{array}$ & $\begin{array}{l}\text { Annual } \\
\text { marijuana } \\
\text { use }^{\mathrm{e}}\end{array}$ & $\begin{array}{l}\text { Current } \\
\text { other illicit } \\
\text { drug use }{ }^{\mathrm{f}, \mathrm{g}}\end{array}$ & $\begin{array}{l}\text { Annual other } \\
\text { illicit drug } \\
u s e^{\mathrm{fhh}}\end{array}$ \\
\hline \multicolumn{8}{|l|}{ Wave 1 (modal age 18$)^{\mathrm{i}}$} \\
\hline $\begin{array}{l}\text { Fraternity/sorority membership } \\
\text { status }\end{array}$ & $119.95^{* * *}$ & $144.73^{* * *}$ & $12.35^{* * *}$ & $6.15^{*}$ & $27.92^{* * *}$ & NS & NS \\
\hline Gender & $147.18^{* * *}$ & $63.82^{* * *}$ & NS & $24.11^{* * *}$ & $40.44^{* * *}$ & $4.94^{*}$ & $5.68^{*}$ \\
\hline Membership status $\times$ gender & $18.38^{* * *}$ & $4.98^{*}$ & NS & $7.32^{* *}$ & $14.24^{* * *}$ & NS & NS \\
\hline \multicolumn{8}{|l|}{ Wave $2(\text { modal ages } 19 / 20)^{\mathrm{i}}$} \\
\hline $\begin{array}{l}\text { Fraternity/sorority membership } \\
\text { status }\end{array}$ & $261.36^{* * *}$ & $307.08^{* * *}$ & $9.39^{* *}$ & $11.19^{* * *}$ & $30.69^{* * *}$ & NS & $6.14^{*}$ \\
\hline Gender & $152.74^{* * *}$ & $60.09^{* * *}$ & NS & $46.89^{* * *}$ & $58.26^{* * *}$ & $16.99^{* * *}$ & $30.57^{* * *}$ \\
\hline Membership status $\times$ gender & $13.45^{* * *}$ & NS & NS & $10.08^{* *}$ & $17.05^{* * *}$ & $4.69^{*}$ & $10.93^{* * *}$ \\
\hline \multicolumn{8}{|l|}{ Wave 3 (modal ages 21/22) } \\
\hline $\begin{array}{l}\text { Fraternity/sorority membership } \\
\text { status }\end{array}$ & $230.55^{* * *}$ & $213.57^{* * *}$ & $11.99^{* * *}$ & $6.56^{* *}$ & $27.11^{* * *}$ & NS & NS \\
\hline Gender & $171.48^{* * *}$ & $94.11^{* * *}$ & NS & $68.99^{* * *}$ & $69.44^{* * *}$ & $16.94^{* * *}$ & $36.12^{* * *}$ \\
\hline Membership status $\times$ gender & $6.29^{*}$ & NS & NS & $8.16^{* *}$ & $10.44^{* *}$ & NS & $3.91^{*}$ \\
\hline
\end{tabular}

NS $=$ not statistically significant. ${ }^{*} P<0.05,{ }^{* *} P<0.01,{ }^{* * *} P<0.001$. All ANOVAs were full factorial, $F$ statistics are shown above. ${ }^{a}$ Heavy episodic drinking in past 2 weeks, $\mathrm{df}=1 / 5734$ at wave $1, \mathrm{df}=1 / 5740$ at wave 2 and $\mathrm{df}=1 / 5128$ at wave $3 .{ }^{\mathrm{b}}$ Current alcohol use, $\mathrm{df}=1 / 5756$ at wave $1, \mathrm{df}=1 / 5759$ at wave 2 and $\mathrm{df}=1 / 5142$ at wave $3 .{ }^{\mathrm{c}}$ Current cigarette use, $\mathrm{df}=1 / 5813$ at wave $1, \mathrm{df}=1 / 5811$ at wave 2 and $\mathrm{df}=1 / 5155$ at wave 3 . ${ }^{\mathrm{d}}$ Current marijuana use, $\mathrm{df}=1 / 5819$ at wave $1, \mathrm{df}=1 / 5819$ at wave 2 and $\mathrm{df}=1 / 5164$ at wave 3 . ${ }^{\mathrm{e}}$ Annual marijuana use, $\mathrm{df}=1 / 5825$ at wave $1, \mathrm{df}=1 / 5832$ at wave 2 and $\mathrm{df}=1 / 5167$ at wave $3 .{ }^{\mathrm{f} O t h e r ~ i l l i c i t ~ d r u g s ~ i n c l u d e d ~ a m p h e t a m i n e s, ~ b a r b i t u r a t e s, ~ t r a n q u i l i z e r s, ~ L S D, ~ p s y c h e d e l i c s ~ o t h e r ~ t h a n ~ L S D, ~ c o c a i n e, ~ h e r o i n ~ a n d ~ n a r-~}$ cotics other than heroin. ${ }^{\mathrm{g}}$ Current illicit drug use other than marijuana, $\mathrm{df}=1 / 5865$ at wave $1, \mathrm{df}=1 / 5871$ at wave 2 and df $=1 / 5195$ at wave 3 . ${ }^{\mathrm{h}} \mathrm{An}$ nual illicit drug use other than marijuana, $\mathrm{df}=1 / 5869$ at wave $1, \mathrm{df}=1 / 5875$ at wave 2 and $\mathrm{df}=1 / 5200$ at wave 3 . Fraternity and sorority status at waves 1 and 2 was based on fraternity and sorority membership status at wave $2 .{ }^{j}$ Fraternity and sorority status at wave 3 was based on fraternity and sorority membership status at wave 3 .

sororities engage in significantly higher rates of substance use relative to their college peers (e.g. Lo \& Globetti 1995; Cashin et al. 1998; Wechsler et al. 2000; Strote et al. 2002).

The findings from the present study extend what is known about substance use within the college environment in several important ways. First, although it is known that members of fraternities and sororities report elevated levels of alcohol use during college, the present study shows that these elevated rates were present before college, while these individuals were still seniors in high school. Secondly, the present study shows that members of fraternities and sororities also report higher rates of cigarette use, marijuana use and other illicit drug use than non-members while in college. Thirdly, trends in elevated substance use among fraternity and sorority members were evident across multiple cohorts of college students between 1988 and 1997. Finally, the present study takes a longitudinal approach in examining the pattern of substance use over time and reveals evidence to indicate that both selection and socialization effects contribute to the high mean levels of substance use- - particularly, heavy episodic drinking and annual marijuana use-among members of fraternities and sororities. It is also clear that average levels of substance use increase for college students in general, regardless of fraternity/soror- ity membership, which is consistent with previous research (Bachman et al. 1997, 2002; Schulenberg \& Maggs 2002).

The selection effects found in the present study indicate that greater substance use precedes entrance into college for those who become members of fraternities and sororities as undergraduates in the United States. These selection effects are more powerful for young men than women. These results are consistent with previous work indicating that selection effects often lead to different socialization effects because individuals are influenced by the environments they select based on their own personal characteristics (e.g. Schulenberg et al. 1994; Lo \& Globetti 1995; Borsari \& Carey 1999; Read et al. 2002).

There is also evidence for socialization effects, in that heavy episodic drinking and annual marijuana use increased over time as a function of fraternity and sorority membership status during college. One could argue that these changes actually reflect selection effects, in that those who want to join fraternities or sororities may have increased their substance use regardless of whether they actually joined; however, the finding that heavy episodic drinking and annual marijuana use between waves 2 and 3 increased among those students who were members in wave 3 only (as they started their membership) to a greater extent than among those students who were 
Table 4 Longitudinal substance use by fraternity or sorority membership status: means and standard deviations.

\begin{tabular}{|c|c|c|c|c|}
\hline & $\begin{array}{l}\text { Heavy episodic } \\
\text { drinking } \\
M(S D)\end{array}$ & $\begin{array}{l}\text { Current } \\
\text { cigarette use } \\
M(S D)\end{array}$ & $\begin{array}{l}\text { Annual } \\
\text { marijuana use } \\
M(S D)\end{array}$ & $\begin{array}{l}\text { Annual other } \\
\text { illicit drug use } \\
M(S D)\end{array}$ \\
\hline \multicolumn{5}{|l|}{ Wave 1 (modal age 18) } \\
\hline \multicolumn{5}{|l|}{ Men } \\
\hline Member waves 2 and 3 & $2.11(1.39)$ & $1.39(0.85)$ & $1.86(1.63)$ & $1.048(0.18)$ \\
\hline Member neither wave & $1.52(1.05)$ & $1.29(0.77)$ & $1.57(1.40)$ & $1.045(0.22)$ \\
\hline Member wave 2 only & $2.18(1.53)$ & $1.27(0.71)$ & $1.99(1.92)$ & $1.083(0.28)$ \\
\hline Member wave 3 only & $1.73(1.21)$ & $1.41(0.80)$ & $1.72(1.64)$ & $1.059(0.24)$ \\
\hline \multicolumn{5}{|l|}{ Women } \\
\hline Member waves 2 and 3 & $1.48(0.98)$ & $1.38(0.74)$ & $1.48(1.14)$ & $1.038(0.18)$ \\
\hline Member neither wave & $1.29(0.75)$ & $1.31(0.78)$ & $1.45(1.20)$ & $1.038(0.18)$ \\
\hline Member wave 2 only & $1.47(1.03)$ & $1.39(0.79)$ & $1.51(1.20)$ & $1.033(0.16)$ \\
\hline Member wave 3 only & $1.27(0.69)$ & $1.24(0.66)$ & $1.39(1.11)$ & $1.036(0.14)$ \\
\hline \multicolumn{5}{|l|}{ Wave 2 (modal ages 19/20) } \\
\hline \multicolumn{5}{|l|}{ Men } \\
\hline Member waves 2 and 3 & $2.82(1.40)$ & $1.55(1.02)$ & $2.32(1.92)$ & $1.072(0.23)$ \\
\hline Member neither wave & $1.88(1.28)$ & $1.41(0.96)$ & $1.84(1.72)$ & $1.048(0.20)$ \\
\hline Member wave 2 only & $2.44(1.49)$ & $1.47(0.96)$ & $2.45(2.25)$ & $1.100(0.31)$ \\
\hline Member wave 3 only & $2.16(1.40)$ & $1.54(1.00)$ & $2.00(1.79)$ & $1.068(0.28)$ \\
\hline \multicolumn{5}{|l|}{ Women } \\
\hline Member waves 2 and 3 & $2.22(1.33)$ & $1.51(0.87)$ & $1.74(1.42)$ & $1.039(0.17)$ \\
\hline Member neither wave & $1.54(1.02)$ & $1.42(0.96)$ & $1.69(1.48)$ & $1.042(0.18)$ \\
\hline Member wave 2 only & $1.75(1.18)$ & $1.56(1.11)$ & $1.83(1.46)$ & $1.034(0.11)$ \\
\hline Member wave 3 only & $1.81(1.20)$ & $1.31(0.81)$ & $1.71(1.41)$ & $1.018(0.07)$ \\
\hline \multicolumn{5}{|l|}{ Wave 3 (modal ages 21/22) } \\
\hline \multicolumn{5}{|l|}{ Men } \\
\hline Member waves 2 and 3 & $3.10(1.44)$ & $1.65(1.19)$ & $2.66(2.23)$ & $1.099(0.24)$ \\
\hline Member neither wave & $2.10(1.34)$ & $1.47(1.07)$ & $1.99(1.89)$ & $1.064(0.26)$ \\
\hline Member wave 2 only & $2.37(1.24)$ & $1.71(1.16)$ & $2.56(2.31)$ & $1.083(0.22)$ \\
\hline Member wave 3 only & $2.66(1.40)$ & $1.64(1.16)$ & $2.27(1.97)$ & $1.066(0.17)$ \\
\hline \multicolumn{5}{|l|}{ Women } \\
\hline Member waves 2 and 3 & $2.28(1.35)$ & $1.61(1.04)$ & $1.84(1.47)$ & $1.035(0.15)$ \\
\hline Member neither wave & $1.63(1.10)$ & $1.44(0.99)$ & $1.67(1.50)$ & $1.037(0.16)$ \\
\hline Member wave 2 only & $1.83(1.27)$ & $1.49(1.11)$ & $1.78(1.53)$ & $1.022(0.13)$ \\
\hline Member wave 3 only & $1.95(1.26)$ & $1.42(0.88)$ & $1.72(1.37)$ & $1.022(0.08)$ \\
\hline
\end{tabular}

a'Other illicit drugs included amphetamines, barbiturates, tranquilizers, LSD, psychedelics other than LSD, cocaine, heroin and narcotics other than heroin. Cell sizes based on heavy episodic drinking in past 2 weeks. Male: member waves 2 and 3, 248; member neither wave, 1290; member wave 2 only, 52; member wave 3 only, 101. Female: member waves 2 and 3, 352; member neither wave, 1876; member wave 2 only, 91; member wave 3 only, 163.

Table 5 Summary of repeated measures analyses of variance longitudinal results: waves 1, 2 and 3.

\begin{tabular}{|c|c|c|c|c|}
\hline Measurement occasions and factors & $\begin{array}{l}\text { Heavy episodic } \\
\text { drinking }^{\text {a }}\end{array}$ & $\begin{array}{l}\text { Current } \\
\text { cigarette use }^{\mathrm{b}}\end{array}$ & $\begin{array}{l}\text { Annual } \\
\text { marijuana use }\end{array}$ & $\begin{array}{l}\text { Annual other } \\
\text { illicit drug use }^{\mathrm{d}}\end{array}$ \\
\hline \multicolumn{5}{|l|}{ Within subjects } \\
\hline Time & $143.99^{* * *}$ & $38.54^{* * *}$ & $54.11^{* * *}$ & NS \\
\hline Time $\times$ membership status & $15.58^{* * *}$ & NS & $2.45^{*}$ & NS \\
\hline Time $\times$ gender & NS & $3.05^{*}$ & $5.59^{* *}$ & NS \\
\hline Time $\times$ membership status $\times$ gender & NS & NS & NS & NS \\
\hline
\end{tabular}

NS = not statistically significant. ${ }^{*} P<0.05,{ }^{* *} P<0.01,{ }^{* * *} P<0.001$. All RMANOVAs were full factorial, and $F$ statistics and dfs were based on Pillai's trace. ${ }^{a}$ Heavy episodic drinking in past 2 weeks, $\mathrm{df}=2 / 4054$ for time and $\mathrm{df}=6 / 8110$ for membership status $\times$ time. ${ }^{b}$ Current cigarette use, $\mathrm{df}=2 / 4163$ for time and gender $\times$ time. ${ }^{c}$ Annual marijuana use, $\mathrm{df}=2 / 4189$ for time and gender $\times$ time, $\mathrm{df}=6 / 8380$ for membership status $\times$ time. ${ }^{\mathrm{d}}$ Other illicit drugs included amphetamines, barbiturates, tranquilizers, LSD, psychedelics other than LSD, cocaine, heroin and narcotics other than heroin. 

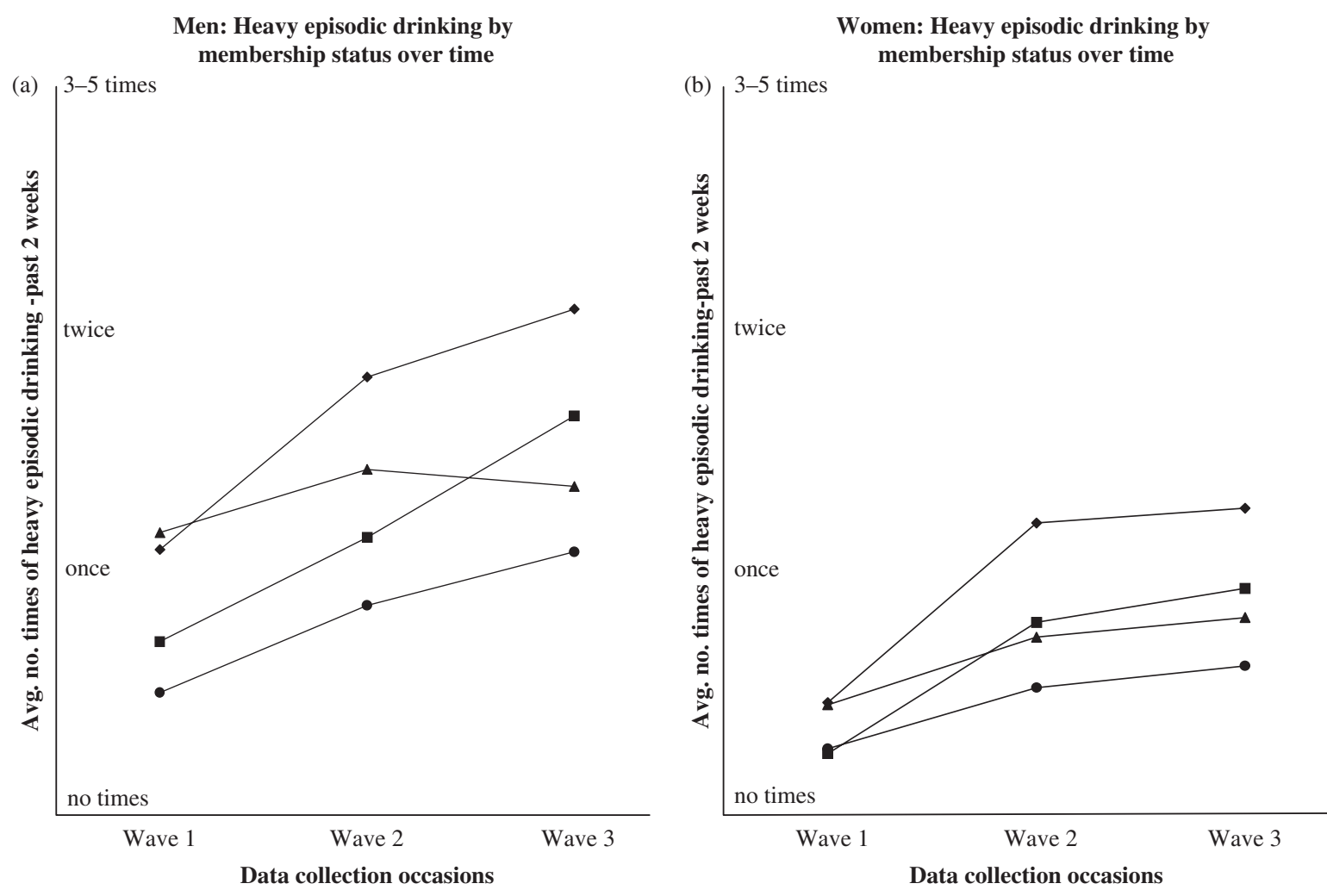

Figure I Heavy episodic drinking by membership status over time for men (a) and women (b) across all waves. $\bullet$, Member both waves; - member neither wave; $\boldsymbol{\Lambda}$, member wave 2 only; $\mathbf{\square}$, member wave 3 only

members in wave 2 only (as they ended their membership) seems more consistent with a socialization explanation. Another interpretation could be that there was a mismatch between those members who drink relatively less and their environment at wave 2 and they chose to disaffiliate. More research is needed to examine the reasons for leaving fraternities and sororities as a way of understanding these selection and socialization effects more effectively.

Membership in fraternities or sororities may serve to increase heavy drinking due to the central role of alcohol in these social organizations and the enabling environment of fraternity and sorority houses (Borsari \& Carey 1999). Indeed, previous cross-sectional research has shown that residence in fraternities and sororities is associated with an increased risk of heavy drinking (Lo \& Globetti 1995; Cashin et al. 1998; Larimer et al. 2000; Wechsler et al. 2002) and marijuana use (Bell et al. 1997). It is noteworthy in the present study that the increases among members of fraternities or sororities observed for heavy episodic drinking and annual marijuana use were not as strong for current cigarette smoking or annual illicit drug use other than marijuana. This shows the power of a multivariate and longitudinal approach, especially one that examines measures of different substances and their use across three or more waves in the consideration of collegiate substance use, as we and others have suggested recently (e.g. Schulenberg et al. 2001; Sher et al. 2001; O'Malley \& Johnston 2002; Schulenberg \& Maggs 2002; Bartholow et al. 2003).

Just as the selection effects seem to be more powerful for men than for women, the socialization effects may also be more powerful for men than for women. We found that the change over time in annual marijuana use and current cigarette use varies significantly according to gender. In general, undergraduate men tend to increase their substance use more than women over the course of their college careers. This is consistent with previous work that substance use during late adolescence and early adulthood is more prevalent among men than women (Gledhill-Hoyt et al. 2000; Office of Applied Studies 2003; Johnston et al. 2004).

The longitudinal findings of the present study have important implications for planning prevention and intervention efforts. For instance, because it is clear that members of fraternities and sororities have the highest levels of substance use while in high school, intervention efforts might be focused on individuals interested in joining fraternities and sororities before they arrive at college. Further, due to the high prevalence of substance use before entering college, efforts aimed at fraternity and sorority members should focus more attention on sec- 

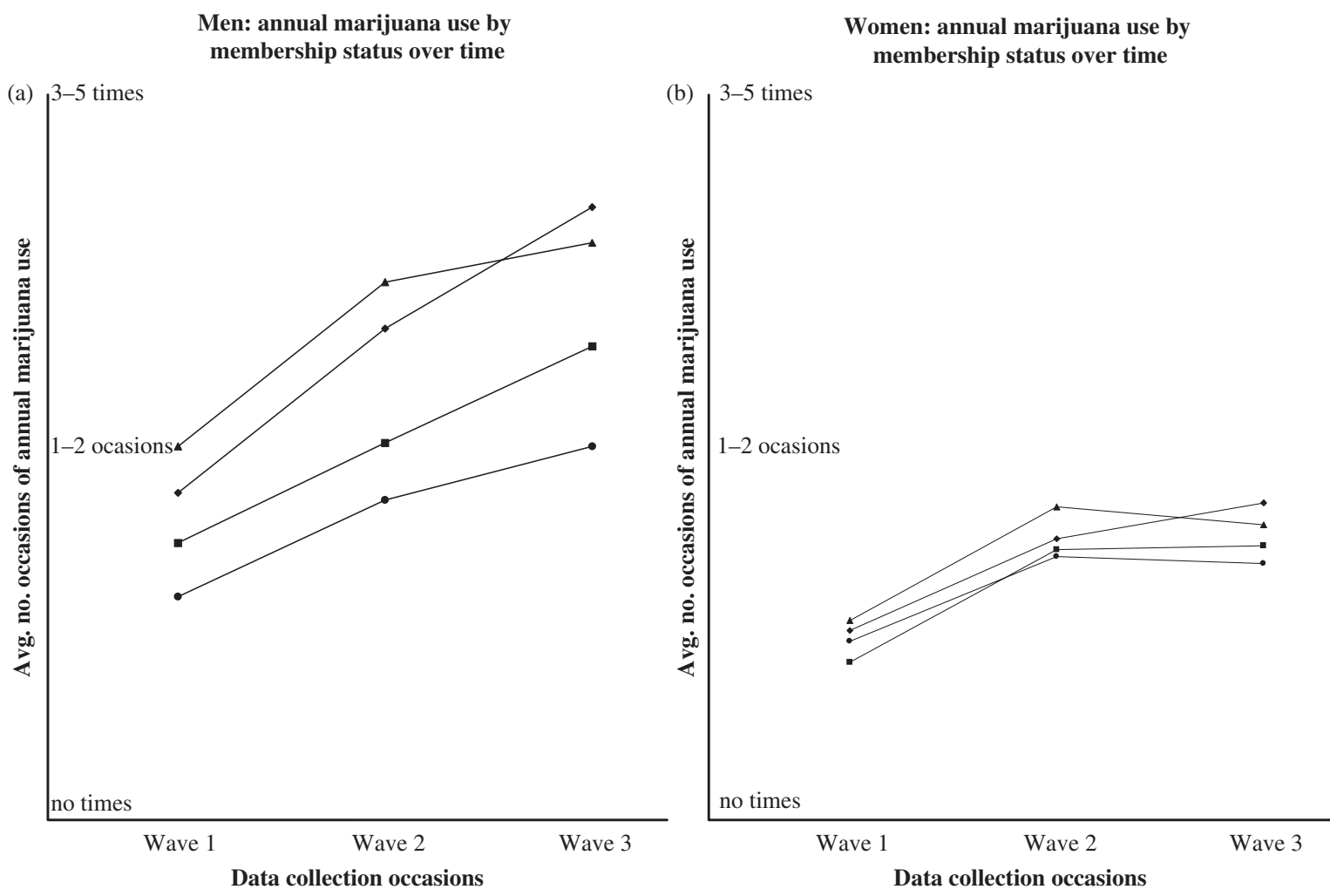

Figure 2 Annual marijuana use by membership status over time for (a) men and (b) women across all waves. $\bullet$, Member both waves; member neither wave; $\boldsymbol{\Delta}$, member wave 2 only; $\mathbf{\square}$, member wave 3 only

ondary rather than primary prevention during college. In addition to heavy alcohol use, precollege secondary prevention efforts must take into account the misuse of other substances. Finally, college prevention efforts aimed toward fraternity and sorority members should especially target heavy episodic drinking and marijuana use based on the significant increases for these drugs during college.

\section{Strengths and limitations}

The present study has several strengths that build upon past college-based research examining the relationship between substance use and membership in fraternities and sororities. First, this study includes nation-wide samples of full-time college students in order to generalize our findings beyond a single college or university. Second, multiple cohorts of college students were followed longitudinally across three waves, enabling an assessment of developmental change. To date, many previous national efforts have been cross-sectional and have not examined selection effects by prospectively following samples from high school through college. Finally, the focus of the present study extends beyond alcohol to other licit and illicit substances.
The current study has some limitations that should be taken into account while considering implications of the findings. First, because the present study represented secondary analyses, the survey items in the original questionnaire limited what could be examined. For example, the survey items did not specify to which fraternity or sorority any particular student may have belonged. It should not be assumed that fraternity and sorority organizations are homogenous in nature, because there are important differences between and within institutions. Next, the small cell sizes of some of the groups limited the inclusion of other potentially relevant factors, such as race/ethnicity, personality characteristics and living arrangements. A related concern is attrition, particularly differential attrition with respect to substance use; as is common in longitudinal studies on substance use, heavy substance users were less likely to remain in our sample. Given that fraternity members tend to be heavier users (and use before entering college), it is likely that our findings reflect a conservative bias, suggesting an underestimate of membership effects. Finally, based on the non-experimental nature of the present study, we acknowledge the complexity involved in distinguishing the impact of selection and socialization effects during college. Therefore, we have considered various possible interpretations of our findings. 


\section{Future research}

Past research has shown that heavy drinking and other substance use, except for cigarette use, tend to decline as young adults assume postcollege responsibilities (e.g. Bachman et al. 1997; Sher \& Gotham 1999; Schulenberg et al. 2001; Johnston et al. 2004). An important question for future research, based on the present findings, is whether the typical postcollege decline in substance use holds equally well for those who were involved in fraternities and sororities in college. There is some evidence based on a single university study that the high rates of heavy drinking among fraternity and sorority members relative to non-members during college are no longer apparent in the years following college (Sher et al. 2001; Bartholow et al. 2003). Whether these findings extend to other substances and other samples are important questions for future longitudinal research.

\section{Acknowledgements}

The Monitoring the Future data were collected under research grant R01 DA01411 (PI: L. Johnston) from the National Institute on Drug Abuse, and the work of the second to sixth authors on this manuscript was supported by this grant. For the first author, work on this manuscript was supported by a National Research Service Award T32 DA07267 (PI: C. Boyd) from the National Institute on Drug Abuse. The authors would like to thank Tanya Hart for her editorial assistance, as well as the respondents and school personnel for their continued participation in the study.

\section{References}

Bachman, J. G., Johnston, L. D. \& O'Malley, P. M. (2001) The Monitoring the Future Project After Twenty-Seven Years: Design and Procedures. Monitoring the Future Occasional Paper no. 54. Ann Arbor, MI: Institute for Social Research.

Bachman, J. G., O’Malley, P. M., Schulenberg, J. E., Johnston, L. D., Bryant, A. L. \& Merline, A. C. (2002) The Decline of Substance Use in Young Adulthood: Changes in Social Activities, Roles, and Beliefs. Mahwah, NJ: Lawrence Erlbaum Associates.

Bachman, J. G., Wadsworth, K. N., O'Malley, P. M., Johnston, L. D. \& Schulenberg, J. E. (1997) Smoking, Drinking and Drug Use in Young Adulthood: The Impacts of New Freedoms and New Responsibilities. Mahwah, NJ: Lawrence Erlbaum Associates.

Baer, J. S., Kivlahan, D. R. \& Marlatt, G. A. (1995) High-risk drinking across the transition from high school to college. Alcoholism: Clinical and Experimental Research, 19, 54-61.

Bartholow, B. D., Sher, K. J. \& Krull, J. L. (2003) Changes in heavy drinking over the third decade of life as a function of collegiate fraternity and sorority involvement: a prospective multilevel analysis. Health Psychology, 22, 616-626.

Bell, R., Wechsler, H. \& Johnston, L. D. (1997) Correlates of college student marijuana use: results of a US national survey. Addiction, 92, 571-581.
Berkowitz, A. D. \& Perkins, H. W. (1987) Recent research on gender differences in collegiate alcohol use. Journal of American College Health, 36, 123-129.

Borsari, B. E. \& Carey, K. B. (1999) Understanding fraternity drinking: five recurring themes in the literature. Journal of American College Health, 48, 30-37.

Cashin, J. R., Presley, C. A. \& Meilman, P. W. (1998) Alcohol use in the Greek system: follow the leader? Journal of Studies on Alcohol, 59, 63-70.

Gfroerer, J. C., Greenblatt, J. C. \& Wright, D. A. (1997) Substance use in the US college-age population: differences according to educational status and living arrangement. American Journal of Public Health, 87, 62-65.

Gledhill-Hoyt, J., Lee, H., Strote, J. \& Wechsler, H. (2000) Increased use of marijuana and other illicit drugs at US colleges in the 1990s: results of three national surveys. Addiction, 95, 1655-1667.

Hingson, R. W., Heeren, T., Zakocs, R. C., Kopstein, A. \& Wechsler, H. (2002) Magnitude of alcohol-related mortality and morbidity among U.S. college students ages 18-24. Journal of Studies on Alcohol, 63, 136-144.

Johnston, L. D., O'Malley, P. M., Bachman, J. G. \& Schulenberg, J. E. (2004) National Survey Results on Drug Use from the Monitoring the Future Study, 1975-2003, II. College Students and Adults Ages 19-45. NIH Publication 04-5508. Bethesda, MD: National Institute on Drug Abuse.

Larimer, M. E., Anderson, B. K., Baer, J. S. \& Marlatt, G. A. (2000) An individual in context: predictors of alcohol use and drinking problems among Greek and residence hall students. Journal of Substance Abuse, 11, 53-68.

Lo, C. C. \& Globetti, G. (1995) The facilitating and enhancing roles Greek associations play in college drinking. International Journal of the Addictions, 30, 1311-1322.

McCabe, S. E. (2002) Gender differences in collegiate risk factors for heavy episodic drinking. Journal of Studies on Alcohol, 63, 49-56.

Mohler-Kuo, M., Lee, J. E. \& Wechsler, H. (2003) Trends in marijuana and other illicit drug use among college students. Results from 4 Harvard School of Public Health College Alcohol Study Surveys: 1993-2001. Journal of American College Health, 52, 17-24.

O'Malley, P. M. \& Johnston, L. D. (2002) Epidemiology of alcohol and other drug use among American college students. Journal of Studies on Alcohol Supplement 14, 23-39.

Office of Applied Studies (2003) Results from the 2002 National Survey on Drug Use and Health: National Findings. DHHS Publication no. SMA 03-3836, NHSDA, Series H-22. Rockville, MD: Substance Abuse and Mental Health Services Administration.

Pascarella, E. T. \& Terenzini, P. T. (1991) How College Affects Students. San Francisco: Jossey-Bass Publishers.

Presley, C. A., Meilman, P. W. \& Cashin, J. R. (1996) Alcohol and Drugs on American College Campuses: Use, Consequences, and Perceptions of the Campus Environment, vol. IV, pp. 1992-1994. Carbondale, IL: Core Institute.

Read, J. P., Wood, M. D., Davidoff, O. J., McLacken, J. \& Campbell, J. F. (2002) Making the transition from high school to college: the role of alcohol-related social influence factors in students' drinking. Substance Abuse, 23, 53-65.

Schulenberg, J., Bachman, J. G., O'Malley, P. M. \& Johnston, L. D. (1994) High school educational success and subsequent substance use: a panel analysis following adolescents into young adulthood. Journal of Health Social Behavior, 35, 4562. 
Schulenberg, J. E. \& Maggs, J. L. (2002) A developmental perspective on alcohol use and heavy drinking during adolescence and the transition to young adulthood. Journal of Studies on Alcohol Supplement 14, 54-70.

Schulenberg, J., Maggs, J. L., Long, S. W., Sher, K. J., Gotham, H. J., Baer, J. S., Kivlahan, D. R., Marlatt, G. A. \& Zucker, R. A. (2001) The problem of college drinking: insights from a developmental perspective. Alcoholism: Clinical and Experimental Research, 25, 473-477.

Schulenberg, J., O'Malley, P. M., Bachman, J. G., Wadsworth, K. N. \& Johnston, L. D. (1996) Getting drunk and growing up: trajectories of frequent binge drinking during the transition to young adulthood. Journal of Studies on Alcohol, 57, 289-304.

Sher, K. J., Bartholow, B. D. \& Nanda, S. (2001) Short- and longterm effects of fraternity and sorority membership on heavy drinking: a social norms perspective. Psychology of Addictive Behaviors, 15, 42-51.

Sher, K. J. \& Gotham, H. J. (1999) Pathological alcohol involvement: a developmental disorder of young adulthood. Development and Psychopathology, 11, 933-956.
Strote, J., Lee, J. E. \& Wechsler, H. (2002) Increased MDMA use among college students: results of a national survey. Journal of Adolescent Health, 30, 64-72.

Wechsler, H., Isaac, N. E., Grodstein, F. \& Sellers, D. E. (1994) Continuation and initiation of alcohol use from the first to the second year of college. Journal of Studies on Alcohol, 55, 4145 .

Wechsler, H., Lee, J. E., Kuo, M. \& Lee, H. (2000) College binge drinking in the 1990s: a continuing problem. Results of the Harvard School of Public Health 1999 College Alcohol Study. Journal of American College Health, 48, 199-210.

Wechsler, H., Lee, J. E., Kuo, M., Seibring, M., Nelson, T. F. \& Lee, H. (2002) Trends in college binge drinking during a period of increased prevention efforts. Findings from 4 Harvard School of Public Health College Alcohol Study Surveys: 1993-2001. Journal of American College Health, 50, 203-217.

Yacoubian, G. S. (2003) Correlates of ecstasy use among students surveyed through the 1997 College Alcohol Study. Journal of Drug Education, 33, 61-69. 